\title{
Hesperidin inhibits HeLa cell proliferation through apoptosis mediated by endoplasmic reticulum stress pathways and cell cycle arrest

Yaoxian Wang ${ }^{1+}$, Hui Yu ${ }^{2+}$, Jin Zhang $^{3}$, Jing Gao ${ }^{1}$, Xin Ge ${ }^{4}$ and Ge Lou ${ }^{1 *}$

\begin{abstract}
Background: Hesperidin (30, 5, 9-dihydroxy-40-methoxy-7-orutinosyl flavanone) is a flavanone that is found mainly in citrus fruits and has been shown to have some anti-neoplastic effects. The aim of the present study was to investigate the effect of hesperidin on apoptosis in human cervical cancer HeLa cells and to identify the mechanism involved.

Methods: Cells were treated with hesperidin $(0,20,40,60,80$, and $100 \mu \mathrm{M})$ for 24,48 , or $72 \mathrm{~h}$ and relative cell viability was assessed using the 3-(4, 5-dimethylthiazol-2-yl)-2, 5-diphenyltetrazolium bromide (MTT) assay.

Results: Hesperidin inhibited the proliferation of HeLa cells in a concentration- and time-dependent manner. Hesperidin-induced apoptosis in HeLa cells was characterized by increased nuclear condensation and DNA fragmentation. Furthermore, increased levels of GADD153/CHOP and GRP78 indicated hesperidin-induced apoptosis in HeLa cells involved a caspase-dependent pathway, presumably downstream of the endoplasmic reticulum stress pathway. Both of these proteins are hallmarks of endoplasmic reticulum stress. Hesperidin also promoted the formation of reactive oxygen species, mobilization of intracellular $\mathrm{Ca}^{2+}$, loss of mitochondrial membrane potential $(\Delta \psi \mathrm{m})$, increased release of cytochrome $\mathrm{c}$ and apoptosis-inducing factor from mitochondria, and promoted capase-3 activation. It also arrested HeLa cells in the G0/G1 phase in the cell cycle by downregulating the expression of cyclinD1, cyclinE1, and cyclin-dependent kinase 2 at the protein level. The effect of hesperidin was also verified on the human colon cancer cell HT-29 cells.
\end{abstract}

Conclusion: We concluded that hesperidin inhibited HeLa cell proliferation through apoptosis involving endoplasmic reticulum stress pathways and cell cycle arrest.

Keywords: Hesperidin, HeLa cells, ROS, MMP, Apoptosis, ER stress, Cell cycle arrest

\section{Background}

Cervical cancer is the second most common female cancer worldwide, but it is the leading malignancy in incidence and mortality among women in some developing countries $[1,2]$. Several treatments are available for cervical cancer, but each of them has obvious drawbacks. Surgical treatment is usually restricted only to patients at early stages of the disease and young patients who are willing to accept the loss of fertility [3]. Radiotherapy and chemotherapy are not specific to cancer cells and often produce severe adverse effects, including gastrointestinal

\footnotetext{
*Correspondence: gexincom@163.com

${ }^{\dagger}$ Equal contributors

'Department of Gynecology, Third Affiliated Hospital of Harbin Medical University, 150 Hapin Road, Harbin, Heilongjiang Province 150086, China Full list of author information is available at the end of the article
}

reactions, bone marrow suppression, immune suppression, nerve injury, hair loss, and development of secondary malignancies [3]. Despite advances in treatment, up to $35 \%$ patients will develop recurrent or metastatic disease when the results of initial treatment are poor. New therapeutic strategies must be developed to improve survival. However, finding safer and more efficient treatments remains an arduous task.

Recent studies have focused on the anti-tumor properties of natural products because these medicines may have fewer side effects and may be more suitable for long-term use compared with synthetic medicines. Hesperidin (30, 5, 9-dihydroxy-40-methoxy-7-orutinosyl flavone, HES) belongs to the flavanone class of flavonoids that is found mainly in citrus fruits $[4,5]$. It has many 
pharmacological activities such as antioxidant, antiinflammatory, and anti-mutagenic effects; inhibition of prostaglandin synthesis; modulation of drug metabolizing enzymes; and inhibition of tumor promoters [6-11]. The effects of HES on the prevention and treatment of disease have recently received considerable attention [12], particularly its anti-neoplastic effects [13, 14]. Dietary HES inhibits carcinogenesis in the urinary bladder, colon, lung, and breast in rat models [15-19]. In addition, in vitro and in vivo studies have demonstrated the potential of HES as a cytotoxic agent against a variety of malignant human cancers such as colon [20-23], pancreatic [24], hepatocellular [25], breast [26], prostate [26] and leukemia [27]. However, the molecular mechanisms for the growth inhibition and cytotoxicity of HES in HeLa cells are poorly understood.

In recent years, apoptosis has emerged as a major mechanism by which anticancer agents eliminate pre-neoplastic or neoplastic cells. It has been shown that HES can induce apoptosis through a number of mechanisms including increasing nuclear condensation and DNA fragmentation [20]. These effects of HES are mediated through regulation of the B-cell lymphoma-2 (Bcl-2) family [24, 28], activation of caspase-9 and -3 [24], induction of cell-cycle arrest [26], elevation of the levels of reactive oxygen species (ROS) [22, 23], and decreased levels of nuclear factor$\kappa B(N F-\kappa B)$ [25-27]. HES was also found to inhibit cyclooxygenase-2 (COX-2), matrix metalloproteinase-2 (MMP-2), and MMP-9 [29], and regulate phosphorylation of mitogen-activated protein kinases (MAPKs) including c-Jun N-terminal kinases (JNKs) and extracellular signalregulated kinases (ERKs) [25, 30, 31]. However, there are no available data on the mechanism of HES inhuman cervical cancer HeLa cells in vitro. The aim of the present study was to investigate the potential anticancer effects of HES on human cervical cancer HeLa cells and the underlying molecular mechanisms.

\section{Methods}

\section{Chemicals and reagents}

HES, MTT (3-(4, 5-dimethylthiazol-2-yl)-2, 5-diphenylte trazolium bromide), and 2, 7-dichlorodihydrofluorescein diacetate (DCFH-DA) were obtained from Sigma Chemical Co. (St. Louis, MO, USA). The primers of cyclinD1 and cyclinE for real-time polymerase chain reaction (PCR) were purchased from Genscript (Nanjing, Jiangsu, China). Antibodies against GADD153/CHOP, GRP78, cytochrome c, apoptosis-inducing factor (AIF), cleavedcaspase-3, cyclinD1, cyclinE1, cyclin-dependent kinase 2 (CDK2), glyceraldehyde-3-phosphate dehydrogenase $(\mathrm{GAPDH})$, and $\beta$-actin were purchased from Cell Signaling Technology (Boston, MA, USA). Fluorescence-conjugated secondary antibodies and Dulbecco's modified Eagle's medium were purchased from Invitrogen (Carlsbad, CA,
USA). All other chemicals were obtained in the highest purity commercially available.

\section{Cell culture}

Human cervical cancer HeLa cells and human colon cancer HT-29 cells were obtained from American Type Culture Collection (ATCC). Cells were cultured in Dulbecco's modified Eagle's medium supplemented with $10 \%(v / v)$ fetal calf serum, $100 \mu \mathrm{g} / \mathrm{mL}$ streptomycin, and $100 \mathrm{U} / \mathrm{mL}$ penicillin. Cultures were maintained at $37^{\circ} \mathrm{C}$ in a humidified incubator in an atmosphere of $5 \% \mathrm{CO}_{2}$. Confluent cells were used for the following experiments.

\section{MTT cell proliferation assay}

Cell proliferation was determined by MTT assay. In brief, HeLa cells and HT-29 cells in logarithmic growth phase were seeded into 96-well plates at $1 \times 10^{4}$ cells/well followed by incubation at $37^{\circ} \mathrm{C}$ for $24 \mathrm{~h}$ to allow attachment. Then the cells were treated with $\operatorname{HES}(0,20,40,60$, 80 , and $100 \mu \mathrm{M})$ for 24,48 , or $72 \mathrm{~h}$. Six wells were included in each group. MTT $(20 \mu \mathrm{L}$ of $5 \mathrm{mg} / \mathrm{mL})$ was added to each well and incubated at $37{ }^{\circ} \mathrm{C}$ for $4 \mathrm{~h}$. The supernatant was discarded and the formazan precipitates were dissolved in $150 \mu \mathrm{L}$ of dimethyl sulfoxide (DMSO) by gentle shaking for $10 \mathrm{~min}$. After dissolution, absorbance (A) was measured at $490 \mathrm{~nm}$ on a microplate reader (Tecan, Meilen, Zurich, Switzerland). Background absorbance of the medium without cells was subtracted from all experimental samples. Percent viability was calculated as [value of drug-treated group (A)/control group (A)] $\times$ $100 \%$. Each assay was carried out three times, and the results were expressed as the mean $( \pm$ SEM).

\section{Detection of apoptotic cells by Hoechst 33342 staining and DNA laddering fragmentation}

The apoptosis of HeLa cells and HT-29 cells was detected using the Hoechst 33342 assay kit (Beyotime Institute of Biotechnology, China). HeLa cells $\left(2 \times 10^{5}\right.$ cells/well) were seeded into a 6-well plate and treated with $\operatorname{HES}(0,40,80$, and $160 \mu \mathrm{M})$ for $48 \mathrm{~h}$. Then the attached cells were washed with phosphate buffered saline (PBS) and fixed with freshly prepared $4 \%$ paraformaldehyde for $30 \mathrm{~min}$. After fixation, the cells were washed with PBS and incubated with Hoechst 33342 staining solution for $5 \mathrm{~min}$. After staining, cells were washed with PBS and anti-fade mounting medium (Beyotime Institute of Biotechnology, Haimen, Jiangsu, China) was added, then the cells were viewed with a fluorescence microscope (Nikon Corporation, Tokyo, Japan). Apoptosis, as indicated by condensed and fragmented nuclei, was observed and recorded with the fluorescence microscope.

The HeLa cells $\left(2 \times 10^{5}\right.$ cells/well $)$ were seeded into a 6-well plate and treated with $\operatorname{HES}(0,40,80$, and $160 \mu \mathrm{M})$ for $48 \mathrm{~h}$. Then the attached cells were washed 
with PBS and the DNA was isolated from HES-treated and control cells use DNA isolation kit (Beyotime Institute of Biotechnology, Haimen, Jiangsu, China), separated by $1.0 \%$ agarose gel electrophoresis, viewed and photographed by an ultraviolet light gel documentation system.

\section{Detection of ROS, intracellular $\mathrm{Ca}^{2+}$ concentrations and mitochondrial membrane potential $(\Delta \Psi \mathrm{m})$ in HeLa cells by flow cytometry}

HeLa cells $\left(1 \times 10^{6}\right.$ cells/well $)$ were seeded into a 6-well plate and treated with $\operatorname{HES}(0,40,80$, and $160 \mu \mathrm{M})$ for $48 \mathrm{~h}$. Then cells were harvested for detection of ROS, intracellular $\mathrm{Ca}^{2+}$ concentration, and $\Delta \Psi \mathrm{m}$.

The level of ROS in HeLa cells was examined by flow cytometry (Becton Dickinson Corporation, USA), using DCFH-DA (Sigma). The cells were harvested and washed twice with PBS. The cells were then re-suspended in $500 \mu \mathrm{L}$ of DCFH-DA $(10 \mu \mathrm{M})$, incubated at $37{ }^{\circ} \mathrm{C}$ for $30 \mathrm{~min}$, and the level of ROS in the HeLa cells was examined by flow fluorescence activated cell sorting (FACS).

The level of intracellular $\mathrm{Ca}^{2+}$ in HeLa cells was determined by flow cytometry, using Indo 1/AM (Calbiochem; La Jolla, CA, USA). The cells were harvested and washed twice with PBS. The cells were re-suspended in Indo $1 / \mathrm{AM}(3 \mu \mathrm{g} / \mathrm{mL})$, incubated at $37{ }^{\circ} \mathrm{C}$ for $30 \mathrm{~min}$, and then analyzed to detect the changes of cytoplasmic $\mathrm{Ca}^{2+}$ levels using flow cytometry.

The $\Delta \Psi \mathrm{m}$ in HeLa cells was determined by flow cytometry using 3, 3-dihexyloxacarbocyanine iodide (DiOC6) (4 $\mu \mathrm{M})$. The cells were harvested, washed twice, re-suspended in $500 \mu \mathrm{L}$ of DiOC6 $(4 \mu \mathrm{M})$ and incubated at $37{ }^{\circ} \mathrm{C}$ for $30 \mathrm{~min}$ before being analyzed by flow cytometry to detect the changes in $\Delta \Psi \mathrm{m}$.

To detect ROS, intracellular $\mathrm{Ca}^{2+}$ concentration, and $\triangle \Psi \mathrm{m}$ in Hela cells pre-treated with BAPTA or NAC, $1 \times 10^{6}$ cells/well of HeLa cells were plated into a 6-well plate and pre-treated with BAPTA (a $\mathrm{Ca}^{2+}$ chelator, $10 \mu \mathrm{M}$ ) or NAC (a ROS inhibitor, $1 \mathrm{mM}$ ) before adding $80 \mu \mathrm{M}$ of HES for 24 or $4 \mathrm{~h}$ incubation. Then levels of ROS, intracellular $\mathrm{Ca}^{2+}$ concentrations, and $\Delta \Psi \mathrm{m}$ were measured using flow cytometry as the same methods described above.

\section{Cell cycle assay by flow cytometry}

The distribution of HeLa cells in the phases of the cell cycle was quantified using flow cytometry. HeLa cells $\left(1 \times 10^{6}\right.$ cells/well $)$ were seeded into a 6 -well plate and treated with $\operatorname{HES}(0,40,80$, and $160 \mu \mathrm{M})$ for $48 \mathrm{~h}$. Then the cells were harvested by treatment with trypsin and centrifuged at $7500 \mathrm{rpm}$ for $5 \mathrm{~min}$. The cells were washed with PBS, and stained with $500 \mu \mathrm{L}$ of propidium iodide in the dark at room temperature for $15 \mathrm{~min}$ according to the manufacturer's protocol (Beyotime Institute of Biotechnology, Haimen, Jiangsu, China). The cells were then analyzed by flow cytometry. The percentage of cells in the different cell cycle phases (G0/G1, S, and $\mathrm{G} 2 / \mathrm{M}$ phase) was calculated using Coulter Epicx XL-MCL DNA analysis software.

\section{Western blot analysis}

Following treatment with $\operatorname{HES}(0,40,80$, and $160 \mu \mathrm{M})$ for $48 \mathrm{~h}, \mathrm{HeLa}$ cells were washed with ice-cold PBS and collected in lysis buffer (50 mM Tris, $\mathrm{pH} 7.4,150 \mathrm{mM}$ sodium chloride, $1 \%$ NP-40, $0.25 \%$ sodium deoxycholate, $0.1 \%$ sodium dodecyl sulfate ( $\mathrm{SDS}$ ), $1 \mathrm{mM}$ sodium orthovanadate, $1 \mathrm{mM}$ sodium fluoride, $1 \mathrm{mM}$ ethylenediaminetetraacetic acid (EDTA), $1 \mathrm{mM}$ phenylmethanesulfonyl fluoride (PMSF) and $1 \mu \mathrm{g} / \mathrm{mL}$ leupeptin). The supernatant was obtained by centrifugation at 13,500 rpm for $20 \mathrm{~min}$. Total protein was extracted and protein concentration was determined by the Bradford assay.

For Western blots, $120 \mu \mathrm{g}$ of protein from each sample were subjected to electrophoresis on $12 \%$ SDS-PAGE and separated proteins were transferred onto a polyvinylidene fluoride (PVDF) membrane. The PVDF membrane was blocked with $5 \%$ non-fat milk powder $(w / v)$ at room temperature for $2 \mathrm{~h}$, then incubated with the primary antibodies against GADD153/CHOP (1:500), GRP78(1:500), cytochrome c (1:500), AIF (1:500), cleaved-caspase-3 (1:500), cyclinD1 (1:500), cyclinE1 (1:500), CDK2 (1:500), GAPDH (1:1000), and $\beta$-actin (1:500) at $4{ }^{\circ} \mathrm{C}$ overnight. After washing, the membrane was incubated with fluorescence-conjugated secondary antibodies (anti-rabbit or anti-mouse, 1:10,000) at room temperature for $50 \mathrm{~min}$. GAPDH or $\beta$-actin was used as an internal control to account for protein loading and transfer from the gel to the membranes. Bands on the Western blots were quantified using the Odyssey infrared imaging system (LI-COR, USA). All results represent of three independent experiments.

\section{Statistical analysis}

Data were reported as means \pm SEM of at least three independent experiments. For statistical analysis, oneway ANOVA was used for comparison of one variance among groups and two-way ANOVA was used for comparison of two independent variances among groups followed by the Tukey's post hoc test. $P$ values less than 0.05 were considered significant.

\section{Results}

HES-induced morphological changes and anti-proliferation effect in HeLa cells and HT-29 cells

HeLa cells and HT-29 cells were incubated with HES (0, $20,40,60,80$, and $100 \mu \mathrm{M})$ for $48 \mathrm{~h}$. The morphology of the cells was examined using a phase contrast microscope. In the presence of HES, HeLa cells showed round morphology with a small amount of shrinkage and 
nuclear condensation, and a proportion of the cells showed swelling, cell membrane lysis, and disintegration of organelles, suggesting HES-induced toxicity to HeLa cells (Fig. 1a and c).

Cell viability was evaluated by the MTT assay at 24 , 48 , and $72 \mathrm{~h}$ and results were reported as relative cell viability (\%). All data were normalized to the control group (100 \%). Treatment with HES significantly reduced cell viability compared to the control group (Fig. $1 \mathrm{~b}$ and $\mathrm{d}$ ) and the effect of HES on cell viability was concentration-and time-dependent. Cells incubated with $100 \mu \mathrm{M}$ HES for $72 \mathrm{~h}$ showed the maximum antiproliferative effect, with cell viability decreased to $12 \%$ of the control cells. This result suggests that HES inhibits proliferation of HeLa cells in a concentrationand time-dependent manner.

\section{HES-induced apoptosis in HeLa cells and HT-29 cells}

HeLa cells and HT-29 cells were treated with HES (0, $40,80$, and $160 \mu \mathrm{M})$ for 48 hand apoptosis was assessed with Hoechst 33342 apoptosis detection kit. Representative images of Hoechst 33342 staining are shown in Fig. 2a and c. HES-treated cells exhibited typical morphological changes indicating apoptosis. The nuclei with condensed chromatin showed more fluorescence than the nuclei in normal cells. Apoptotic HeLa cells also displayed round and shrunken cell bodies (white arrows in Fig. 2a and c). The number of apoptotic HeLa cells increased as the concentration of HES increased (Fig. $2 b$ and d), suggesting that HES-induced apoptosis of HeLa cells might contribute to reduced cell viability.

\section{HES-induced DNA fragmentation in HeLa cells}

DNA fragmentation is considered another hallmark of apoptosis. HeLa cells were treated with $\operatorname{HES}(0,40,80$, and $160 \mu \mathrm{M})$ for $48 \mathrm{~h}$ and DNA fragmentation was detected using the DNA laddering fragmentation assay. The cleaved DNA fragments in apoptotic HeLa cells were separated by agarose gel electrophoresis (Fig. 3). Staining of the gel with ethidium bromide revealed

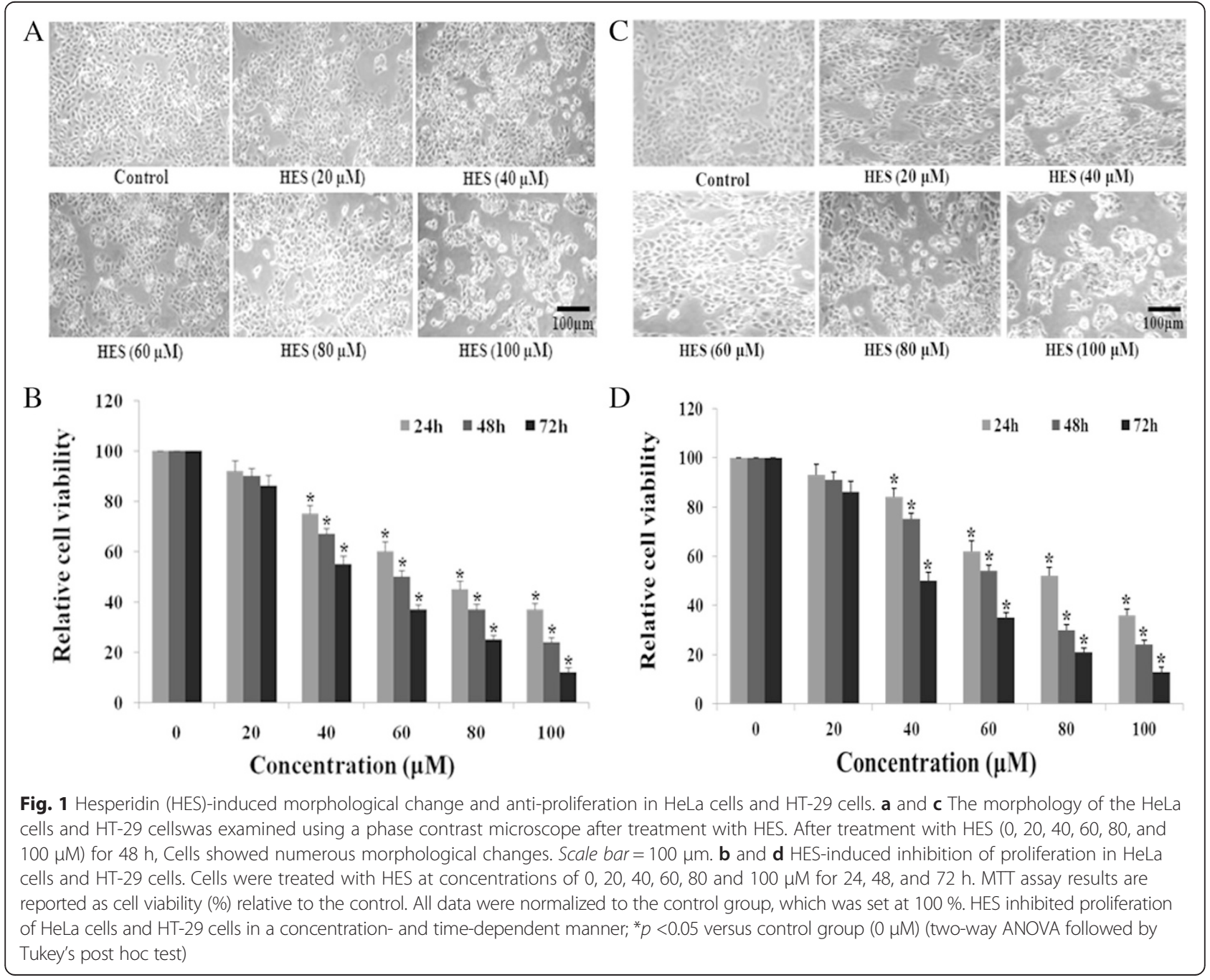




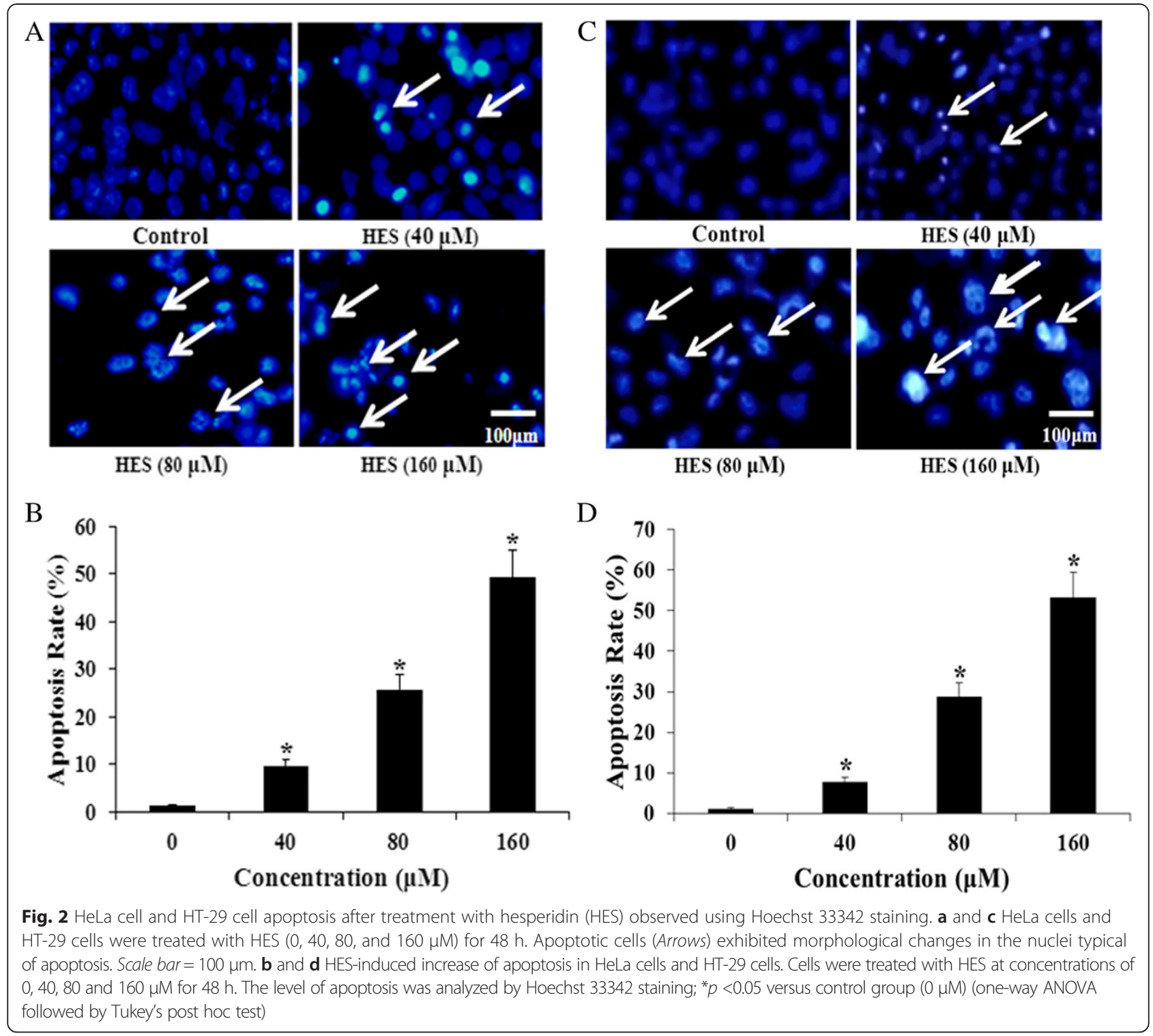

typical laddering pattern of multimers of 500-1000 bases. Treatment with 80 and $160 \mu \mathrm{M}$ HES markedly increased DNA fragmentation in HeLa cells. HES induced DNA fragmentation in a concentration-dependent manner.

HES-induced increase in ROS and cytoplasmic $\mathrm{Ca}^{2+}$ levels and decrease in $\Delta \Psi_{m}$ in HeLa cells

To evaluate HES-induced oxidative stress in HeLa cells, the level of ROS was detected by flow cytometry after cells were treated with HES $(0,40,80$, and $160 \mu \mathrm{M})$ for $48 \mathrm{~h}$. The level of ROS was increased in the HES-treated groups in a concentration-dependent manner. ROS production was maximal after treatment with $160 \mu \mathrm{M}$ HES (Fig. 4a).
Intracellular $\mathrm{Ca}^{2+}$ homeostasis is critical for normal cell function. Previous studies have suggested that increased cytoplasmic $\mathrm{Ca}^{2+}$ is associated with mitochondrial dysfunction and leads to overproduction of ROS. To study the impact of HES treatment on $\mathrm{Ca}^{2+}$ homeostasis in HeLa cells, cytoplasmic $\mathrm{Ca}^{2+}$ was measured by flow cytometry after $48 \mathrm{~h}$ treatment with $\operatorname{HES}(0,40,80$ and $160 \mu \mathrm{M})$. Compared to the control, exposure to $160 \mu \mathrm{M}$ HES resulted in 3.1-fold increase in cytoplasmic $\mathrm{Ca}^{2+}$. The effect of HES on HeLa cytoplasmic $\mathrm{Ca}^{2+}$ displayed concentration-dependence over the concentration range tested (Fig. 4b). HES-induced mobilization of cytoplasmic $\mathrm{Ca}^{2+}$ may be correlated with increased ROS and apoptosis in HeLa cells.

Under normal conditions, mitochondria possess a transmembrane electrical potential (negative inside). A 


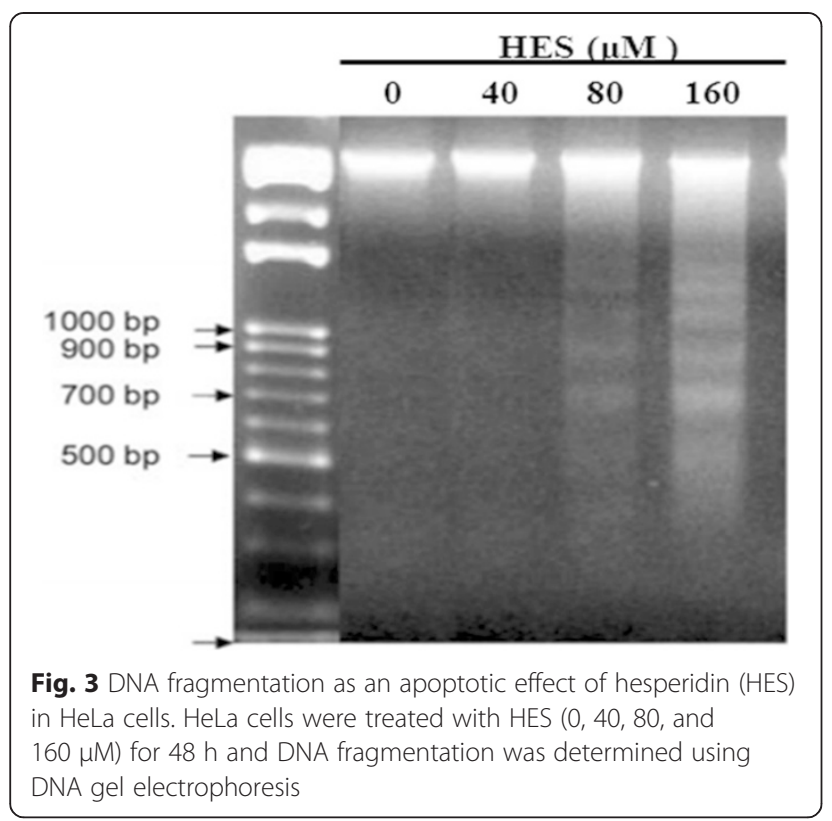

decrease in $\Delta \Psi \mathrm{m}$ results in the release of cytochrome $\mathrm{c}$ into the intermembrane space that is associated with cell apoptosis. To investigate whether HES affects $\Delta \Psi \mathrm{m}$, HeLa cells were treated with $\operatorname{HES}(0,40,80$, and $160 \mu \mathrm{M})$ for $48 \mathrm{~h}$ and $\Delta \Psi \mathrm{m}$ was measured by flow cytometry. Exposure to $40 \mu \mathrm{M}$ HES decreased $\Delta \Psi \mathrm{m}$ by about $20 \%$ and $160 \mu \mathrm{M}$ HES exposure decreased $\Delta \Psi \mathrm{m}$ by up to $70 \%$. The effectiveness of HES in decreasing $\Delta \Psi \mathrm{m}$ exhibited concentration-dependence (Fig. 4c).

Above results suggested that HES-induced ROS formation led to cytotoxicity and apoptosis and triggered intracellular $\mathrm{Ca}^{2+}$ mobilization. To further test the contribution of calcium mobilization in HES-induced ROS in HeLa cells, we evaluate the effect of NAC, a well-known antioxidant, and BAPTA, a calcium inhibitor, on HES-induced changes of ROS, intracellular $\mathrm{Ca}^{2+}$ and $\triangle \Psi \mathrm{m}$ in HeLa cells. HES-induced increases of ROS and cytoplasmic $\mathrm{Ca}^{2+}$ were significantly suppressed by pre-treatment with $10 \mu \mathrm{M}$ BAPTA or $1 \mathrm{mM}$ NAC (Figs. 5a-b and 6a-b). Moreover, pre-treatment with BAPTA or NAC inhibited HES-induced decrease of $\triangle \Psi \mathrm{m}$ level in HeLa cells (Figs. $5 \mathrm{c}$ and $6 \mathrm{c}$ ). All these results suggested that HES-induced oxidative stress were responsible for HES-induced cytotoxicity and apoptosis through intracellular $\mathrm{Ca}^{2+}$ mobilization.

HES-induced cell cycle arrest at G0/G1 phase of HeLa cells To gain insight into the mechanism of inhibition of cell growth by HES, effects of HES on the distribution of HeLa cells in the cell cycle was determined by flow cytometry. HeLa cells were treated with HES $(0,40,80$, and $160 \mu \mathrm{M}$ ) for $48 \mathrm{~h}$. HES treatment induced cell cycle arrest in HeLa cells at the G0/G1 phase in a concentration-dependent manner (Table 1). Compared to the control cells $(42.10 \pm 2.42 \%$ of cells in G0/G1), 40,80 , and $160 \mu \mathrm{M}$ HES treatment increased the cell population in G0/G1 phase by 1.22-, 1.43-, and 1.71-fold $(p<0.05)$, respectively. HES-induced cell cycle arrest in HeLa cells exhibited a concentration-dependence.

\section{HES increased the levels of GADD153/CHOP, GRP78,cytochromec, AIF, and cleaved-caspase-3} in HeLa cells

The above results suggested that HES-induced apoptosis in HeLa cells involved ROS and calcium-mediated
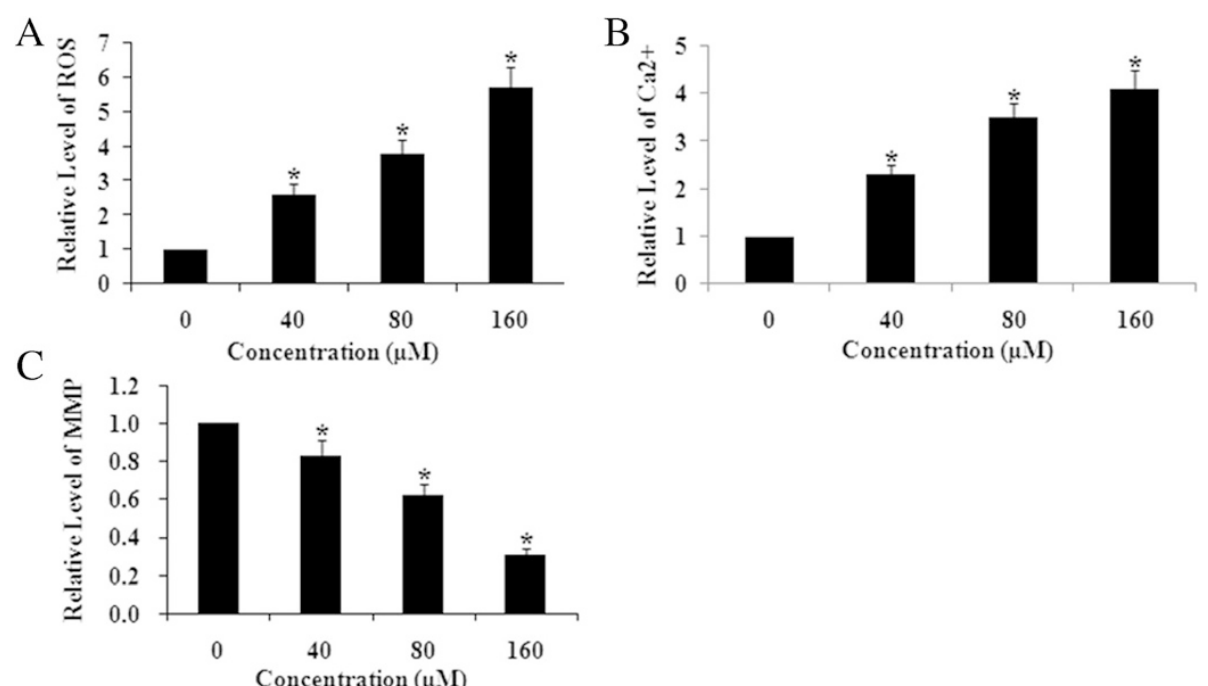

Fig. 4 Hesperidin (HES) increased reactive oxygen species (ROS) and cytoplasmic $\mathrm{Ca}^{2+}$ and decreased mitochondrial membrane potential ( $\left.\Delta \Psi \mathrm{m}\right)$ in HeLa cells. HeLa cells were treated with $\operatorname{HES}(0,40,80$, and $160 \mu \mathrm{M})$ for $48 \mathrm{~h}$. The levels of ROS (a), Ca ${ }^{2+}$ Concentrations $(\mathbf{b})$ and $\Delta 4 \mathrm{~m}(\mathbf{c})$ were analyzed by flow cytometry; ${ }^{*} p<0.05$ versus control group $(0 \mu \mathrm{M})$ (one-way ANOVA followed by Tukey's post hoc test) 
A

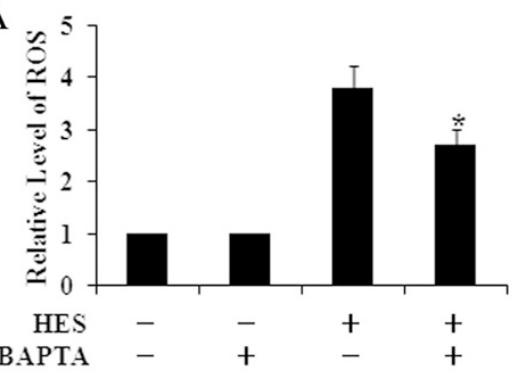

C

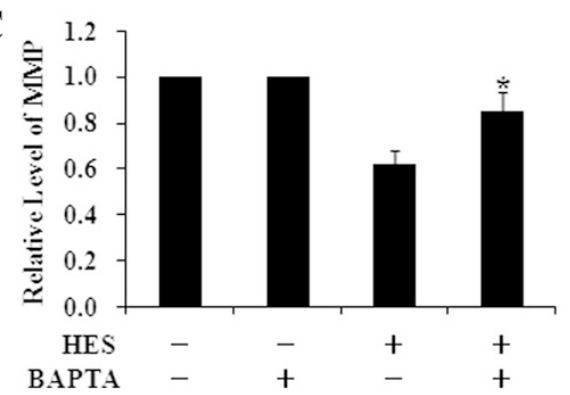

B

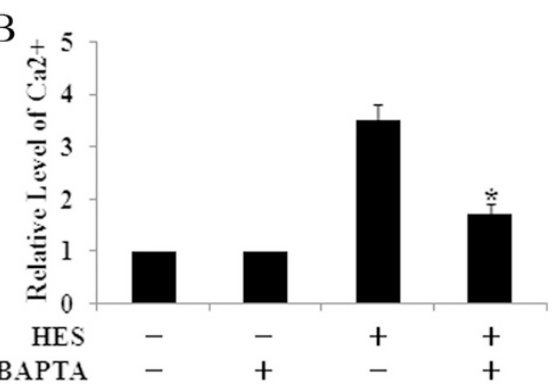

Fig. 5 The increase of ROS, $\mathrm{Ca}^{2+}$ Concentrations and Mitochondrial Membrane Potential ( $\left.\Delta \psi_{\mathrm{m}}\right)$ level induced by HES ( $80 \mu \mathrm{M}$, $\left.48 \mathrm{~h}\right)$ could be significantly suppressed when pre-treatment with BAPTA for $24 \mathrm{~h}$. The levels of ROS $(\mathbf{a}), \mathrm{Ca}^{2+}$ concentrations (b) and $\Delta \psi \mathrm{m}(\mathbf{c})$ were analyzed by flow cytometry; ${ }^{*} p<0.05$ versus HES (+) and BAPTA (-) group (One-way ANOVA followed by Tukey's post hoc test)

mitochondrial pathways in which mitochondrial dysfunction, especially the loss of $\Delta \Psi \mathrm{m}$, led to release of cytochrome c, AIF, and cellular inhibitors of apoptosis (cIAPs) from the mitochondria into the cytosol. These changes resulted in the activation of caspase-3, DNA damage, and cell apoptosis [32-37]. To further elucidate the molecular mechanisms underlying HES-induced apoptosis in HeLa cells, we examined levels of proteins in the endoplasmic reticulum (ER) stress pathway. HeLa cells were treated with $\operatorname{HES}(0,40,80$, and $160 \mu \mathrm{M})$ for
A

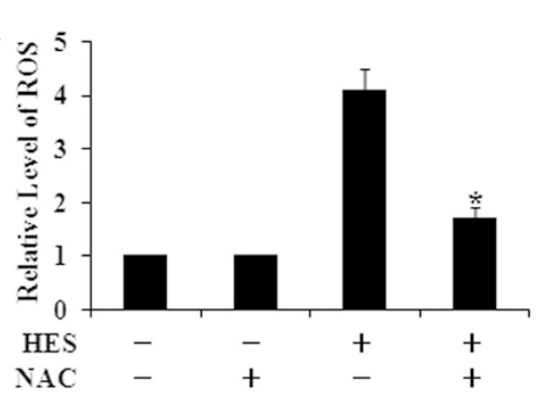

C

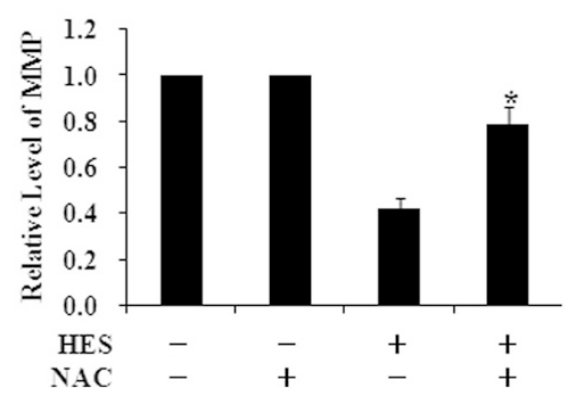

B

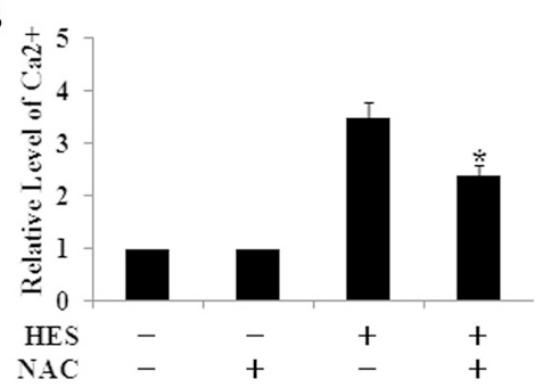

Fig. 6 The increase of ROS, $\mathrm{Ca}^{2+}$ Concentrations and Mitochondrial Membrane Potential $(\Delta \psi \mathrm{m})$ level induced by HES $(80 \mu \mathrm{M}, 48 \mathrm{~h})$ could be significantly suppressed when pre-treatment with NAC for $4 \mathrm{~h}$. The levels of ROS (a), Ca ${ }^{2+}$ concentrations (b) and $\Delta \psi \mathrm{m}$ (c) were analyzed by flow cytometry; ${ }^{*} p<0.05$ versus HES(+) and NAC(-) group (One-way ANOVA followed by Tukey's post hoc test) 
Table 1 Hesperidin (HES)-induced cell cycle arrest at G0/G1 phase of HeLa cells

\begin{tabular}{llll}
\hline $\begin{array}{l}\text { Concentration } \\
(\mu \mathrm{M})\end{array}$ & \multicolumn{3}{l}{ The percentage of cells (\%) } \\
\cline { 2 - 4 } & $\mathrm{G} 0 / \mathrm{G} 1$ & $\mathrm{~S}$ & $\mathrm{G} 2 / \mathrm{M}$ \\
\hline 0 & $42.10 \pm 2.42$ & $31.70 \pm 1.43$ & $26.20 \pm 1.31$ \\
40 & $51.70 \pm 2.84^{*}$ & $26.95 \pm 1.33$ & $21.35 \pm 1.06$ \\
80 & $60.30 \pm 3.11^{*}$ & $20.45 \pm 1.25$ & $19.25 \pm 0.97$ \\
160 & $72.20 \pm 3.49^{*}$ & $12.10 \pm 0.77$ & $15.70 \pm 0.82$ \\
\hline
\end{tabular}

HeLa cells were treated with HES $(0,40,80$, and $160 \mu \mathrm{M})$ for $48 \mathrm{~h}$. The distribution of cells in the cell cycle was measured by flow cytometry; ${ }^{*} p<0.05$ versus control group $(0 \mu \mathrm{M})$ (two-way ANOVA followed by the Tukey's post hoc test)

$48 \mathrm{~h}$ and protein levels were determined by Western blot.

Exposure to $40 \mu \mathrm{M}$ HES increased GADD153/CHOP, GRP78, cytochrome c, AIF, and cleaved-caspase-3 protein levels by 1.98-, 2.03-, 2.13-, 1.63-, and 1.53-fold compared to the control $(p<0.05)$, respectively. Exposure to $160 \mu \mathrm{M}$ HES resulted in the greatest effect on protein levels. The effect of HES on expression of these proteins in HeLa cells was concentration-dependent (Fig. 7).

\section{HES decreased the levels of cyclin D1, cyclin E1, and CDK2 in HeLa cells}

We also investigated the effects of HES on markers of cell cycle distribution in HeLa cells by western blot. HeLa cells were treated with $\operatorname{HES}(0,40,80$, and $160 \mu \mathrm{M})$ for $48 \mathrm{~h}$. In the present study, HES treatment decreased cyclinD1, cyclinE1, and CDK2 protein expression in treated HeLa cells in a concentration-dependent manner. The levels of cyclin D1, cyclin E1, and CDK2 were 0.38-, 0.29-, and 0.31-fold, respectively, of the control level at $160 \mu \mathrm{M}$ (Fig. 8).

\section{Discussion and conclusions}

HES-induced apoptosis has been previously reported in several cell lines [20-31]. Cell death can be divided into necrosis and apoptosis [38]. Apoptosis is a highly regulated, organized, and programmed death process controlling the development and homeostasis of cells in multicellular organisms [39]. Apoptosis can lead to the death of cancer cells without causing damage to normal cells or surrounding tissues [40]. Thus, induction of apoptosis in cancer cells is a key mechanism for anticancer therapy [41]. In this study, we examined the effect of HES on the human cervical cancer HeLa cell line. We observed a concentration-and time-dependent inhibition of proliferation by HES in these cells. The inhibition effect of hesperidin on human colon cancer HT-29 cells is similar to what previously reported in the literature. We concluded that HES inhibited HeLa cell proliferation through apoptosis through a mitochondria-mediated ER stress pathway and cell cycle arrest.

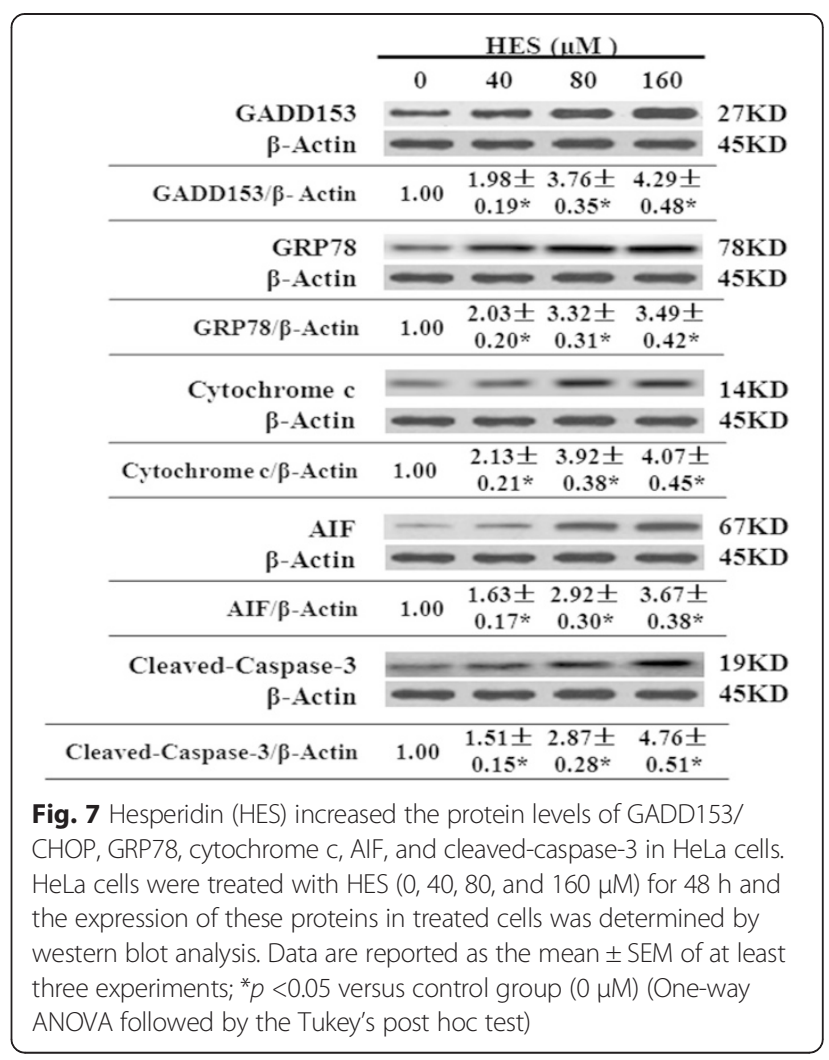

Our results showed HES induced ROS and intracellular $\mathrm{Ca}^{2+}$ mobilization. The generation of ROS may contribute to mitochondrial damage and lead to cell death by acting as apoptotic signals [42]. It has been reported that chemotherapeutic agents induce apoptosis in part by generation of ROS and disruption of redox

\begin{tabular}{|c|c|c|c|c|c|}
\hline \multirow{4}{*}{$\begin{array}{r}\text { Cyclin D1 } \\
\beta \text {-Actin }\end{array}$} & \multicolumn{4}{|c|}{$\operatorname{HES}(\mu \mathrm{M})$} & \multirow{4}{*}{$\begin{array}{l}36 \mathrm{KD} \\
45 \mathrm{KD}\end{array}$} \\
\hline & 0 & 40 & 80 & 160 & \\
\hline & $=$ & $\longrightarrow$ & - & - & \\
\hline & 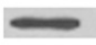 & 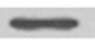 & 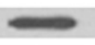 & 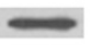 & \\
\hline Cyclin D1/ $\beta$-Actin & 1.00 & $\begin{array}{c}0.91 \pm \\
0.09 *\end{array}$ & $\begin{array}{c}0.54 \pm \\
0.05^{\star}\end{array}$ & $\begin{array}{c}0.38 \pm \\
0.04^{*}\end{array}$ & \multirow{3}{*}{$\begin{array}{l}48 \mathrm{KD} \\
35 \mathrm{KD}\end{array}$} \\
\hline \multirow[b]{3}{*}{ Cyclin E1/GAPDH } & $\longrightarrow$ & $=$ & - & - & \\
\hline & - & 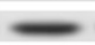 & 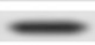 & 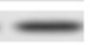 & \\
\hline & 1.00 & $\begin{array}{c}0.83 \pm \\
0.08 *\end{array}$ & $\begin{array}{c}0.52 \pm \\
0.05^{\star}\end{array}$ & $\begin{array}{c}0.29 \pm \\
0.03^{*}\end{array}$ & \multirow{4}{*}{$\begin{array}{l}33 \mathrm{KD} \\
45 \mathrm{KD}\end{array}$} \\
\hline CDK2 & $\longrightarrow$ & $\longrightarrow$ & - & - & \\
\hline$\beta$-Actin & 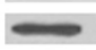 & 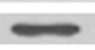 & 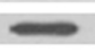 & 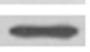 & \\
\hline CDK2/ $\beta$-Actin & 1.00 & $\begin{array}{c}0.85 \pm \\
0.08^{*}\end{array}$ & $\begin{array}{c}0.44 \pm \\
0.04^{*}\end{array}$ & $\begin{array}{c}0.31 \pm \\
0.03^{*}\end{array}$ & \\
\hline \multicolumn{6}{|c|}{$\begin{array}{l}\text { Fig. } 8 \text { Hesperidin (HES) decreased the protein levels of cyclinD1, } \\
\text { cyclinE1, and CDK2 in HeLa cells. HeLa cells were treated with HES } \\
(0,40,80 \text {, and } 160 \mu \mathrm{M}) \text { for } 48 \mathrm{~h} \text { and the expression of these proteins } \\
\text { in treated cells was determined by western blot analysis. Data are } \\
\text { reported as the mean } \pm \text { SEM of at least three experiments; }{ }^{*} p<0.05 \\
\text { versus control group }(0 \mu \mathrm{M}) \text { (One-way ANOVA followed by the } \\
\text { Tukey's post hoc test) }\end{array}$} \\
\hline
\end{tabular}


homeostasis [43, 44]. Our data showed increases in intracellular ROS levels by HES as measured by flow cytometry in HeLa cells. ROS production may lead to ER stress and DNA damage.

Cellular $\mathrm{Ca}^{2+}$ homeostasis is critical for maintaining normal cell function; depletion of ER $\mathrm{Ca}^{2+}$ stores can cause growth arrest and apoptosis [45]. A previous report showed that an increase in intracellular $\mathrm{Ca}^{2+}$ could induce mitochondrial dysfunction, which in turn resulted in the overproduction of $\operatorname{ROS}[46,47]$, in addition, data from another study indicated that ER stress caused accumulation of ROS leading to cell damage, ATP production decrease, and open of a variety of $\mathrm{Ca}^{2+}$ channels in cell membranes and organelles membranes, leading to a significant $\mathrm{Ca}^{2+}$ increase in the cytoplasm. Thus a vicious cycle is formed, triggering an apoptosis process in the cells [48]. We used Western Blot to show that HES increased the levels of GADD153/CHOP and GRP78, hallmarks of ER stress. The relationship between ROS or $\mathrm{Ca}^{2+}$ and apoptosis has been widely investigated in several cancer cell lines $[49,50]$.

Mitochondria play an important role in the regulation of apoptosis via mitochondria-dependent and-independent pathways $[32,51]$. Characteristics of mitochondrial dysfunction are the loss of $\Delta \Psi \mathrm{m}$, increased permeability, and release of cytochrome c, AIF, and cIAPs from the mitochondria into the cytosol. These effects lead to the activation of caspase-3, DNA damage, and cell apoptosis [33-37, 52]. Our results demonstrated marked activation of caspase- 3 by HES presumably resulting from mitochondrial cytochrome $\mathrm{c}$ and AIF release into the cytosol followed the decrease in $\triangle \Psi \mathrm{m}$, suggesting that HESinduced apoptosis takes place partly through the mitochondria-mediated ER stress pathway.

It is well known that the mechanism of some chemotherapeutic drugs interferes with the cell cycle [53]. The cell cycle consists of four distinct phases: G1, S, G2, and M. Activation of each phase is dependent on the proper progression and completion of the previous phase. Recent studies suggest that the cell cycle is preferentially arrested in particular phases or phase transitions, such as G0/G1 or G2/M, in drug-induced apoptosis or autophagy-mediated cell death. Therefore, cell cycle distribution may be significant in developing potential chemotherapy drugs.

In response to extracellular signals, cyclin D is an early expression signal and binds with CDK activating the downstream cascade. Cyclin D binds to CDK4, forming anactivecyclinD-CDK4 complex, which then phosphorylates the retinoblastoma susceptibility protein (Rb). Hyper-phosphorylated Rb dissociates from the E2F/DP1/ $\mathrm{Rb}$ complex activates E2F and results in the transcription of various genes like cyclinE, cyclinA, DNA polymerase, and thymidine kinase. Cyclin $\mathrm{E}$ then binds to
CDK2, forming the cyclinE-CDK2 complex, which pushes the cells from $\mathrm{G} 1$ to $S$ phase $[54,55]$. Gene amplification and abnormal expression of cyclinD1 and cyclinE1 have been described in several human cancers [56]. Our results demonstrated that HES resulted in a concentration-dependent increase in the distribution of HeLa cells at the G0/G1 phase and that the process might be mediated through down-regulation of the expression of cyclin D1, cyclinE1, and CDK2.

From these data, we concluded that apoptosis and cell cycle arrest were involved in anti-tumor effect of HES in HeLa cells. HES has been proven to be an effective medicine possessing many pharmacological activities such as antioxidant, anti-inflammatory, and anti-mutagenic effects, inhibition of prostaglandin synthesis, modulation of drug metabolizing enzymes and inhibition of tumor promoters. The anti-tumor effects of HES on cervical cancer in vivo and the underlying molecular mechanisms require further study, but HES has the potential to be developed as a chemotherapeutic or adjuvant agent for human cervical cancer.

Competing interest

The authors declare that there is no competing interest.

\section{Authors' contributions}

YW and HY designed and conducted the experiments, analyzed the data and wrote the manuscript. JZ, JG, XG conducted the experiments and collected the data. $G L$ designed the experiments and revised the manuscript. All authors read and approved the final manuscript.

\section{Acknowledgement}

This work was supported by the fund from the Department of Education of Heilongjiang Province (No. 12541274), the fund of post-doctoral research project of Heilongjiang Province (No. LBH-Z13150), the Outstanding Young Researcher Grant of Heilongjiang Province (No. JC201108) and the National Natural Science Fund (No. 81372786)

\section{Author details}

${ }^{1}$ Department of Gynecology, Third Affiliated Hospital of Harbin Medical University, 150 Hapin Road, Harbin, Heilongjiang Province 150086, China. ${ }^{2}$ Cardiopulmonary Function Room, Third Affiliated Hospital of Harbin Medical University, 150 Hapin Road, Harbin, Heilongjiang Province 150086, China. ${ }^{3}$ Department of Gynaecology, Fourth Affiliated Hospital of Harbin Medical University, 37 Yiyuan Street, Harbin, Heilongjiang Province 150001, China. ${ }^{4}$ Department of General Surgery, Heilongjiang Provincial Hospital, 82 Zhongshan Road, Harbin, Heilongjiang Province 150036, China.

Received: 20 October 2014 Accepted: 7 October 2015

Published online: 12 October 2015

\section{References}

1. Parkin DM. Global cancer statistics in the year 2000. Lancet Oncol. 2001;2:533-43

2. World Health Organization. Comprehensive cervical cancer control: a guide to essential practice. Geneva: WHO; 2006.

3. Fujimoto J. Novel strategy of anti-angiogenic therapy for uterine cervical carcinomas. Anticancer Res. 2009;29:2665-9.

4. Justesen $U$, Knuthsen $P$, Leth T. Quantitative analysis of flavonols, flavones, and flavanones in fruits, vegetables and beverages by high-performance liquid chromatography with photo-diode array and mass spectrometric detection. J Chromatogr. 1998;A799:101-10.

5. Nielsen SE, Freese R, Klemola P, Mutanen M. Flavonoids in human urine as biomarkers for intake of fruits and vegetables. Cancer Epidemiol Biomarkers Prev. 2002;11:459-66. 
6. Huang MT, Wood AW, Newmark HL, Sayer JM, Yagi H, Jerina DM, et al. Inhibition of the mutagenicity of bay-region diol-epoxides of polycyclic aromatic hydrocarbons by phenolic plant flavonoids. Carcinogenesis. 1983:4:1631-7.

7. Fujik H, Horiuchi T, Yamashita $K$, Hakii H, Suganuma M, Nishino $H$. Inhibition of tumor promotion by flavonoids. Prog Clin Biol Res. 1986;213:429-40.

8. Ratty AK, Das NP. Effects of flavonoids on nonenzymatic lipid peroxidation: structure-activity relationship. Biochem Med Metab Biol. 1988;39:69-79.

9. Galati EM, Monforte MT, Kirjavainen S, Forestieri AM, Trovato A, Tripodo MM. Biological effects of hesperidin, a citrus flavonoid. (Note I): antiinflammatory and analgesic activity. Farmaco. 1994;40:709-12.

10. Ou S. Pharmacological action of hesperidin. Zhong Yao Cai. 2002;25:531-3.

11. Benavente-Garcia O, Castillo J. Update on uses and properties of citrus flavonoids: new findings in anticancer, cardiovascular, and anti-inflammatory activity. J Agric Food Chem. 2008;56:6185-205.

12. Montanari A, Chen J, Widmer W. Citrusflavonoids: a review of past biological activity against disease. Discovery of new flavonoids from Dancy tangerine cold pressed peel oil solids and leaves. Adv Exp Med Biol. 1998;439:103-16.

13. Tian Q, Miller EG, Ahmad H, Tang L, Pati BS. Differential inhibition of human cancer cell proliferation by citrus limonoids. Nutr Cancer. 2001;40:180-4.

14. Winawer S, Fletcher R, Rex D, Bond J, Burt R, Ferrucci J, et al. Colorectal cancer screening and surveillance: clinical guidelines and rationale-update based on new evidence. Gastroenterology. 2003;124:544-60.

15. Yang M, Tanaka T, Hirose Y, Deguchi T, Mori H, Kawada Y. Chemopreventive effects of diosmin and hesperidin on N-butyl-N-(4-hydroxybutyl) nitrosamineinduced urinary bladder carcinogenesis in male ICR mice. Int J Cancer. 1997;73:719-24.

16. Selvaraj A, Jayabal PS, Namasivayam N. Hesperetin exerts dose dependent chemopreventive effect against 1,2-dimethyl hydrazine induced rat colon carcinogenesis. Invest New Drugs. 2009;27:203-13.

17. Sattu K, Gopalakrishnan R, Pandi A, Sundaram J, Thiruvengadam D. Antioxidant and anticancer efficacy of hesperidin in benzo(a)pyrene induced lung carcinogenesis in mice. Invest New Drugs. 2009;27:214-22.

18. Sattu K, Pandi A, Sundaram J, Gopalakrishnan R, Thiruvengadam D. Hesperidin attenuates mitochondrial dysfunction during benzo(a)pyrene-induced lung carcinogenesis in mice. Fund Clin Pharmacol. 2010;25:91-8.

19. Ye L, Chan FL, Chen S, Leung LK. The citrus flavonone hesperetin inhibits growth of aromatase-expressing MCF-7 tumor in ovariectomizedathymic mice. J Nutr Biochem. 2012;23:1230-7.

20. Qiao Z, Yoshinobu H, Naoki Y, Akira M, Koichi K, Hajime O, et al. Further investigation of the modifying effect of various chemopreventive agents on apoptosis and cell proliferation in human colon cancer cells. J Cancer Res Clin Oncol. 2002;128:539-46.

21. Park HJ, Kim MJ, Ha E, Chung JH. Apoptotic effect of hesperidin through caspase3 activation in human colon cancer cells, SNU-C4. Phytomedicine. 2008;15:147-51.

22. Aranganathan S, Nalini N. Efficacy of the potential chemopreventive agent, hesperetin (citrus flavanone), on 1, 2-dimethylhydrazine induced colon carcinogenesis. Food Chem Toxicol. 2009;47:2594-600.

23. Gunasekaran S, Rajamanickam V, Christo PP, Anvarbatcha R, Mohammad AA, Venugopal PM, et al. Role of hesperetin (a natural flavonoid) and its analogue on apoptosis in HT-29 human colon adenocarcinoma cell line-A comparative study. Food Chem Toxicol. 2012;50:660-71.

24. Patil JR, Chidambara Murthy KN, Jayaprakasha GK, Chetti MB, Patil BS Bioactive compounds from Mexican lime (Citrus aurantifolia) juice induce apoptosis in human pancreatic cells. J Agric Food Chem. 2009;57:10933-42.

25. Kuo HL, Ming HY, Shung TK, Che MH, Ching JL, Yung YH, et al. The inhibitory effect of hesperidin on tumor cell invasiveness occurs via suppression of activator protein 1 and nuclear factor-kappaB in human hepatocellular carcinoma cells. Toxicol Lett. 2010;194:42-9.

26. Choong JL, Leslie W, Mary AJ, Vy N, Jessica T, Gregory S. Hesperidin Suppressed Proliferations of both Human Breast Cancer and Androgendependent Prostate Cancer Cells. Phytother Res. 2010;24:S15-9.

27. Ghorbani A, Nazari M, Jeddi-Tehrani M, Zand $H$. The citrus flavonoid hesperidin induces p53 and inhibits NF-KB activation in order to trigger apoptosis in NALM-6 cells: involvement of PPARc-dependent mechanism. Eur J Nutr. 2012;51:39-46

28. Maryam N, Asghar G, Azita HD, Mahmood JT, Hamid Z. Inactivation of Nuclear Factor-KB by citrusflavanone hesperidin contributes to apoptosis and chemo-sensitizing effect in Ramos cells. Eur J Pharmacol. 2011;650:526-33.
29. Sattu K, Pandi A, Sundaram J, Gopalakrishnan R, Thiruvengadam D. Modulatory effect of hesperidin on benzo(a)pyrene induced experimental lung carcinogenesis with reference to COX-2, MMP-2 and MMP-9. Eur J Pharmacol. 2010;649:320-7.

30. Ming HY, Shung TK, Che MH, Ching JL, Kuo HL, Chia CY. Hesperidin inhibited acetaldehyde-induced matrix metalloproteinase-9 gene expression in human hepatocellular carcinoma cells. Toxicol Lett. 2009;184:204-10.

31. Li F, Ye L, Lin SM, Leung LK. Dietary flavones and flavonones display differential effects on aromatase (CYP19) transcription in the breast cancer cells MCF-7. Mol Cell Endocrinol. 2011;344:51-8.

32. Desagher S, Martinou JC. Mitochondria as the central control point of apoptosis. Trends Cell Biol. 2000;10:369-77.

33. Slee EA, Harte MT, Kluck RM, Wolf BB, Casiano CA, Newmeyer DD, et al Ordering the Cytochrome c-initiated Caspase Cascade: Hierarchical Activation of Caspases-2, -3, -6, -7, -8, and -10 in a Caspase-9-dependent Manner. J Cell Biol. 1999;144:281-92.

34. Lee HJ, Lee HJ, Lee EO, Ko SG, Bae HS, Kim CH, et al. Mitochondriacytochrome c-caspase-9 cascade mediates isorhamnetin-induced apoptosis. Cancer Lett. 2008;270:342-53.

35. Thornberry NA, Lazebnik Y. Caspases: enemies within. Science. 1998;281:1312-6.

36. Oltvai ZN, Milliman $\mathrm{CL}$, Korsmeyer $\mathrm{SJ}$. BCl-2 heterodimerizes in vivo with a conserved homolog, Bax, that accelerates programmed cell death. Cell. 1993:74:609-19.

37. Sedlak TW, Oltvai ZN, Yang E, Wang K, Boise LH, Thompson CB, et al. Multiple BCl-2 family members demonstrate selective dimerizations with Bax. Proc Natl Acad Sci U S A. 1995;92:7834-8.

38. Malhi H, Gores GJ. Cellular and molecular mechanisms of liver injury. Gastroenterology. 2008;134:1641-54

39. Muppidi J, Porter M, Siegel RM. Measurement of apoptosis and other forms of cell death. Curr Protoc Immunol. 2004; Chapter 3:Unit 317.

40. Evan Gl, Vousden KH. Proliferation, cell cycle and apoptosis in cancer. Nature. 2001:411:342-8.

41. Kaulmann SH, Earnshaw WC. Induction of apoptosis by cancer chemotherapy. Exp Cell Res. 2000;256:42-9.

42. Clerkin JS, Naughton R, Quiney C, Cotter TG. Mechanismsof ROS modulated cell survival during carcinogenesis. Cancer Lett. 2008;266:30-6.

43. Xia Z, Lundgren B, Bergstrand A, DePierre JW, Nassberger L. Changes in the generation of reactive oxygen species and in mitochondrial membrane potential during apoptosis induced by the antidepressants imipramine, clomipramine, and citalopram and the effects on these changes by $\mathrm{BCl}-2$ and $\mathrm{BCl}-\mathrm{X}(\mathrm{L})$. Biochem Pharmacol. 1999:57:1199-208.

44. Kluck RM, Martin SJ, Hoffman BM, Zhou JS, Green DR, Newmeyer DD. Cytochrome $c$ activation of CPP32-likeproteolysis plays a critical role in a Xenopus cell-free apoptosis system. EMBO J. 1997;16:4639-49.

45. Berridge MJ, Bootman MD, Lipp P. Calcium-a life and death signal. Nature. 1998;395:645-8.

46. Brookes PS, Yoon Y, Robotham JL, Anders MW, Sheu SS. Calcium, ATP and ROS: a mitochondrial love-hate triangle. Am J Physiol Cell Physiol. 2004;287:C817-833.

47. Lee $\mathrm{SH}, \mathrm{Na} \mathrm{SI}, \mathrm{Heo} J \mathrm{~S}, \mathrm{Kim} \mathrm{MH}, \mathrm{Kim}$ YH, Lee MY. Arachidonic acid release by $\mathrm{H}_{2} \mathrm{O}_{2}$ mediated proliferation of mouse embryonic stem cells: Involvementof $\mathrm{Ca}^{2+} / \mathrm{PKC}$ and MAPKs-induced EGFR transactivation. J Cell Biochem. 2009;106:787-97.

48. Haynes CM, Titus EA, Cooper AA. Degradation of misfolded proteins prevents ER-derived oxidative stress and cell death. Mol Cell. 2004;15:767-76.

49. Su CC, Lin JG, Li TM, Chung JG, Yang JS, Ip SW, et al. Curcumin-induced apoptosis of human colon cancer colo 205 cells through the production of ROS, $\mathrm{Ca}^{2+}$ and the activation of caspase-3. Anticancer Res. 2006;26:4379-90.

50. Zhang Y, Soboloff J, Zhu Z, Berger SA. Inhibition of $\mathrm{Ca}^{2+}$ influx is required for mitochondrial reactive oxygen species induced endoplasmic reticulum $\mathrm{Ca}^{2+}$ depletion and cell death in leukemia cells. Mol Pharmacol. 2006;70:1424-34.

51. Kaufmann $\mathrm{SH}$, Hengartner MO. Programmed cell death: alive and well in the new millennium. Trends Cell Biol. 2001;11:526-34.

52. Mantena SK, Baliga MS, Katiyar SK. Grape seed proanthocyanidins induce apoptosis and inhibit metastasis of highly metastatic breast carcinoma cells. Carcinogenesis. 2006;27:1682-91.

53. Schwartz GK, Shah MA. Targeting the Cell Cycle: A New Approach to Cancer Therapy. J Clin Oncol. 2005;23:9408-21.

54. Yamamoto H, Ochiya $T$, Takeshita F, Toriyama-Baba H, Hirai $K$, Sasaki H, et al. Enhanced Skin Carcinogenesis in Cyclin D1-conditional Transgenic Mice Cyclin D1 Alters Keratinocyte Response to Calcium-induced Terminal Differentiation. Cancer Res. 2002:62:1641-7. 
55. Gautschi O, Ratschiller D, Gugger M, Betticher DC, Heighway J. Cyclin D1 in non-small cell lung cancer: A key driver of malignant transformation. Lung Cancer. 2007;55:1-14.

56. Koroleva OA, Tomlinson M, Parinyapong P, Sakvarelidze L, Leader D, Shaw P, et al. CycD1, a Putative G1 Cyclin from Antirrhinum majus, Accelerates the Cell Cycle in Cultured Tobacco BY-2 Cells by Enhancing Both G1/S Entry and Progression through S and G2 Phases. Plant Cell. 2004;16:2364-79.

Submit your next manuscript to BioMed Central and take full advantage of:

- Convenient online submission

- Thorough peer review

- No space constraints or color figure charges

- Immediate publication on acceptance

- Inclusion in PubMed, CAS, Scopus and Google Scholar

- Research which is freely available for redistribution 